\title{
TRADE CREDIT AND BANK FINANCE - EVIDENCE FROM THE VISEGRAD GROUP
}

\section{- Asbiqur Rahman, Zoltan Rozsa, Martin Cepel}

\begin{abstract}
This paper examines whether bank finance is a substitute or complementary to trade credit for small and medium-sized enterprises (SMEs) in the region of the Visegrad Group - the Czech Republic, Poland, Hungary, and the Slovak Republic. This paper uses the data set provided by the Business Environment and Enterprise Performance Survey that was conducted by the European Bank for Reconstruction and Development and the World Bank during the period from 2012 to 2014. Using a sample of 1,140 firms, it was discovered that firms having an overdraft facility from banks use more trade credit, and this supports the complementary theory of bank credit and trade credit. Moreover, the results suggest that companies that are younger, innovative, risky, with a concentrated ownership structure and operated by an experienced manager use more trade credit to purchase their material inputs and services. However, the results also show that service-oriented firms use less trade credit than manufacturing firms.
\end{abstract}

Keywords: trade credit, bank. finance, small and medium-sized enterprises, Visegrad Group JEL Classification: G21, G32, L26

Received: May, 2018

1st Revision: July, 2018

Accepted: July, 2018

\section{INTRODUCTION}

In business, firms often look for innovative ways of strategy and financing (Monni et al. 2017; Ardalan et al., 2017; Vojtovič, 2016; Rajnoha \& Lorincová, 2015). Trade credit is one of the most traditional sources of obtaining financing for small and medium-sized enterprises (SMEs) (Centineo \& Centineo, 2017; Kozubíková et al. 2017; Cole, 2010). The bank credit is supplied to the firm through payment, warranty, with access to collateral and large amounts of paperwork, but trade credit providers give credit with less or no paperwork than is usually required for the bank loan process (Bastos \& Pindado, 2013; Casey \& O’Toole, 2014; Lin \& Chou; 2015). The importance of trade credit is highlighted from a different perspective, as trade credit may affect operating efficiencies and cost improvements, reduce cash uncertainty in the payment, and provide more flexibility to firms in response to variations in demand.

SMEs are an integral part of many developed and developing economies due to their utmost importance in creating new jobs and alleviating unemployment (Beck \& Demirguc-Kunt, 2006; 
Ayyagari et al., 2007; Belas et al., 2015; Virglerova et al., 2016; Adamowicz \& Machla, 2016; Simionescu et al., 2017; Ključnikov et al., 2017; Belas et al., 2017; Zapletalová, 2017; Tvaronavičiené \& Razminienè, 2017). The Business Environment and Enterprise Performance Survey - particularly its fifth wave that took place from 2012 to 2014 - shows that about $48 \%$ of businesses in the Visegrad Group run their business activities in the segment of SMEs. A later study by Daszkiewicz (2014) shows that in 2012, among all businesses, SMEs accounted for $99.8 \%$ in the Czech Republic and Poland. Likewise, $99.9 \%$ of the enterprises in Hungary and the Slovak Republic belonged to this group. However, SMEs have a limited financial capacity, therefore, it is hard for them to grow, and their survival rate is lower than that of large firms (Belas et al., 2015; Krischemann, 2016; Meyer \& Meyer, 2017). SMEs face credit constraints from formal finance providers due to their information opacity and lack of physical assets (Berger \& Udell, 2002; Menkhoff et al., 2012; Rahman et al., 2016; Rahman et al., 2017; Ivanová, 2017). A significant amount of entrepreneurial research has focused on the determinants of financial constraints for SMEs (Beck et al., 2004; Berger et al., 2005; Ayyagari et al., 2007; Kozubíková et al., 2015; Kljucnikov \& Belas, 2016), however, it is still inconclusive whether factors that affect SMEs are financially constrained from banks and other external lending parties.

This paper examines the substitution and complementary effect of trade credit and bank credit in the context of the Visegrad Group. The substitution and complementary effect of finance between trade credit and bank credit is an interesting topic in entrepreneurial research because it relates to both finance and management (Sobekova Majkova, 2016). Firms that face credit contagion from the banks may approach their supplier for short-term financing, by which they can overcome financial difficulties (Coulibaly et al., 2013). However, firms with bank finance may use less trade credit from their suppliers, as they have a loan from the bank (Slavec, 2014). Hence, bank credit and trade credit can be considered each other's substitutes. On the other hand, research shows that firms that use trade credit may have more access to bank finance, and thus trade credit can be considered a complement to bank finance (Demirguc-Kant \& Maksimovic, 2001; Love et al., 2007; Yang, 2011). The reason is that trade credit may signal positive information about the firms to the bank because an access to trade credit may show trade creditor confidence in the borrowers. Taking this into consideration, it is desirable to examine whether bank finance replaces trade credit in the examined countries or trade credit acts as a complement to bank finance. The past literature examines substitution and the complementary effect of trade credit and bank credit in different markets. Nevertheless, substitution and the complementary effect of trade credit and bank credit is yet to be discovered in the region of the Visegrad Group. Thus, this paper can bridge this research gap. Moreover, for more in-depth understanding of bank finance and its effect on trade credit, the bank finance is separated into two sources in the analysis - bank overdraft and line of credit. It also examines the cross-effect of the overdraft and line of credit on trade credit. Therefore, the separation of bank credit can also add a significant value in the context of trade credit and bank credit literature.

The rest of the paper is structured as follows. The second section reviews the relevant literature on the substitution and complementary effect of trade credit and bank credit. The third section presents the data and applied methodology. The outcome of the analysis is revealed in the fourth section, showing the empirical results. The last section concludes the paper and mentions the main findings. 


\section{THEORETICAL BACKGROUND}

In general, the supplier provides trade credit to some selected clients to postpone the payment for goods or services that these clients have already received. Thus, the relationship between the borrower and the supplier of trade credit can imply their long-term relationship (Cuñat, 2007; Cole, 2010). Additionally, firms with better access to the credit market can grant finance to firms that have a limited capacity in accessing credit. Moreover, Bastos \& Pindado (2013) discovered that during a financial crisis, firms that present high levels of days of outstanding sales and a high probability of insolvency use more trade credit. The results suggest that credit constraints during a financial crisis cause firms holding high levels of receivable accounts to postpone payments to suppliers, especially to avoid insolvency.

García-Teruel \& Martínez-Solano (2010) analyze the trade credit granted and received by a panel of 47,197 SMEs in Europe over the period from 1996 to 2002. The authors find that firms with a greater capacity to obtain resources from the capital markets, and hence, more cheaply, grant more trade credit to customers of these firms. Additionally, they also discover that greater investment in the assets of the firms has a positive effect on financing received from their suppliers, and firms having alternative sources of finance suffer less from substitution effect. Yang (2011) examines the causal relationship between trade credit and bank credit during the period of the United States' subprime mortgage crisis. Yang finds that trade credit - or accounts payable as he states - and bank credit are determined simultaneously and negatively relate to each other, which supports the substitution effect of bank credit on trade credit. However, he finds a positive causal relationship between bank credit and accounts receivable, which is considered to be a supporting item of the complementary effect of bank credit on trade credit.

Bastos \& Pindado (2013) support the hypothesis of the substitution between bank credit and trade credit in which firms that delay collection from their customers demand a long-term trade credit from their suppliers. Tsuruta (2013) examines the effect of credit contagion on small firms. Tsuruta argues that the mechanism of this contagion occurs in the bank - bank reduces the amount of lending during a financial shock. This action makes firms that cut off the financing from bank reduce their trade credit to their partners. The analysis of Tsuruta focuses on the fluctuation of trade receivable, trade payable and cash holding of firms. His results imply that trade credit for firms with lower cash holdings fell more during the crisis periods and supply effects cause the reduction of trade credit for these firms. Cole (2010) analyzes the trade credit used by a small firm in the United States. The author finds that non-borrowers are significantly smaller, more profitable, liquid, and of a better credit quality, but hold fewer tangible assets. Another finding is that non-borrowers are more likely to be found in the services industries and the wholesale and retail trade industries. Casey and O'Toole (2014) use the Survey on the Access to Finance of Enterprises done by the European Central Bank. It contains detailed information on the use of specific alternative external financing technologies, subordinated debt and equity financing into a market-financing category, as each type requires small and medium enterprises seeking credit to interact with a formal external financing market. They subdivide credit-rationed firms into two additional categories of credit lines or credit card overdrafts. This calculation highlights the substitution of trade credit for bank credit when constraints relate to volume based-credit rationing. 
Lin \& Chou (2015) use the quarterly data of 1,213 Chinese firms from the first quarter of 2006 until the end of 2012 to examine the relationship between trade credit and bank credit, in which the authors' concern is the size of the firm. They find that not only the supplier of trade credit, but also the receiver, and both large and small firms significantly reduce the amount of trade credits during a financial crisis. Then, large firms provide less trade credit to small firms than they receive from their suppliers. Overall, they find a substitution and complementary effect of trade credit and bank credit. Fatoki \& Odeyemi (2010) indicate that managerial competencies, past business experience, the availability of a business plan, belonging to trade associations, previous relationship, location, business size, insurance, and incorporation are significant determinants of access to trade credit by new small and medium enterprises in the Republic of South Africa.

Atanasova (2012) provides confirmation that the bank needs a firm assessment to determine if it qualifies for a loan. An audited firm is more likely to get the bank financing than the others. This evidence implies that a firm without the audit reports could approach the trade creditor as an alternative financing source. However, Giannetti et al. (2011) find a complementary effect of bank credit and trade credit. They find that firms that access more trade credit from their suppliers tend to borrow a larger sum from the bank. This finding may highlight the fact that the use of trade credit is a positive signal to the banks and a way in which a firm can access more bank finance as well.

\section{DATA, METHODOLOGY AND VARIABLES}

\subsection{Data}

This paper utilizes data from the Business Environment and Enterprise Performance Survey (BEEPS) that was conducted by the European Bank for Reconstruction and Development and the World Bank during the period from 2012 to 2014. The survey is performed to understand the overall business environment and the enterprises' performance related factors in 30 transition and emerging countries including Russia and European and Central Asian countries. The survey covered 1,374 firms in the four examined countries - 254 from the Czech Republic, 310 from Hungary, 542 from Poland, and 268 from the Slovak Republic. According to the aim of the paper, the small and medium enterprises are defined, under the Convention of the Organization for Economic Co-operation and Development and the guidelines given in the survey, as enterprises with a maximum of 250 employees. Due to a large amount of missing data of Poland and after excluding large firms from the sample size, the analysis involves 1,140 records about firms.

\subsection{Methodology}

As the goal of the paper is to examine the substitution and complementary effect of trade credit on bank credit, an ordinary least squares regression model with different specifications of bank credit and trade credit is estimated. 
The empirical model to be estimated is as follows:

Trade_Credit $=\beta_{1}$ Bank credit $+\beta_{2}$ Firm characteristics $+\beta_{3}$ Borrower characteristics $+\beta_{4}$ Market structure $+\varepsilon$

where trade credit is measured by the percentage of material inputs or services purchased on credit over its total purchases. The trade credit information is obtained from the survey question In a fiscal year, what is the percentage of material inputs or services purchased on credit - paid after delivery? The variable is a fraction which ranges from zero percent to one hundred percent. The assumption is that when the trade credit percentage is zero, the firms purchased their supplies totally on cash and when the trade credit percentage is one hundred, it means the firms purchased the product on credit completely. The percentage of purchases between zero and one hundred means a combination of credit purchase and cash purchase.

\subsection{Variables}

To examine the main hypothesis about the complementary and the substitution effect of bank credit on trade credit, there are two proxy variables for bank finance - Bank Overdraft (Over$\mathrm{draft}$ ) and Line of Credit (LOC). At first, the bank overdraft variable is obtained from the survey question At this time, does this establishment have an overdraft facility? The variable is a binary dependent variable that represents whether the firm has an overdraft facility. Then it is identified as one and otherwise as zero. Similarly, the second proxy variable of bank credit comes from the survey question At this time, does this establishment have a line of credit or a loan from a financial institution? According to the nature of the variable, if the firm has a line of credit or a loan from a financial institution, it is identified as one and otherwise as zero. Apart from bank credit, there are controls for firm characteristics, borrower characteristics and a market structure. Firm characteristics or attributes are size, age, trade, service, construction, ownership, audit, quality, innovation, and crime. With respect to firm-specific controls, firm size is measured by the number of full-time employees. This variable is named size (Size). All the firms are divided into three groups - micro, small, and medium. The first group involves firms with up to 9 employees, the second one with a number of employees higher than 10 and lower than 49, and medium sized firms have between 50 and 249 employees. This variable applies, as depending on the firm size, the use of trade credit may differ due to firms' internal and external borrowing capacity. It is found that small firms use more trade credit, as they have little and sometimes no access to bank or external financial support (Cassar, 2004). Similarly, small firms use more trade credit because there is a high default risk associated with bank credit (Huyghebaert, 2006). Hence, a positive relationship between trade credit and the firms' size is expected, and the effect may be stronger for the smaller firms. The sample of the firms is also divided based on their age into four groups. The variable is named age (Age). Huyghebaert et al. (2007) find that younger firms face more credit constraints from external sources and at the same time, they do not have such relationship with the banks. For that reason, younger firms are comfortable to use trade credit. In this respect, Casey \& O’Toole (2014) show that large firms use less trade credit because they have easy access to bank finance and they can invest from their internal cash flows. Thus, a positive relationship between trade credit with younger firms and negative relationship with old or mature firms is expected. Moreover, there are four sector dummy variables - sector 1 is 
manufacturing, sector 2 is trade and wholesale, sector 3 is service, and sector 4 is construction and others. Afterwards, firm ownership structure and the use of trade credit are controlled. It is found that firms that have a high ownership concentration may use more trade credit because the owner has private benefits of control (Huyghebaert \& Gucht, 2004). Due to the private benefit of control, highly concentrated firms may be reluctant to use bank credit because in the event of a loan, the owner may lose the control over the firm by default. Hence, to ensure the owner authority over the firm, the owner may use more trade credit and less bank credit. Thus, a positive relationship between trade credit and ownership concentration is expected. Audit is the successive variable involved in the model (Audit). It is also controlled by firms that have audited financial statements and the trade credit use. It has a value of one if the firm's financial statement is checked by an external audit firm and otherwise, zero. Firms having an audited financial statement can signal better information quality to the external lenders and this might increase their access to external finance by lowering the use of costly trade credit. Atanasova (2012) finds that small firms use more trade credit because they do not have audited financial statements and thus small firms have problems in the process of getting a bank loan. Therefore, trade credit is preferable to bank finance. Firm quality and firm riskiness are also controlled in this empirical model. The quality of the firms is measured by the International Organization for Standardization quality certificate (ISO). The Quality is a dummy variable that takes a value of one if the firms have an ISO quality certificate and otherwise, it takes a value of zero. It is possible that firms with a quality certificate can get easy external financial support due to better information transparency and better borrower quality (Hanedar et al., 2014). As a result, firms with the ISO certificate may ask for more bank finance by lowering trade credit. Hence, it is presumed that there will be a negative relationship between the quality certificate and trade credit. Crime is a measure of firm riskiness, too. It takes a value of one if the firm is affected by theft, robbery, vandalism and arson, otherwise, the value is equal to zero. Small and medium enterprises have a limited access to capital and liquid assets if they are affected by these activities. It might signal more credit risk of the firms which may reduce a formal access to bank finance. However, suppliers can access more accurate information on the business due to a frequent interaction than the bank, which might help the supplier to provide working capital to the business. Hence, a positive relationship between crime and the use of trade credit can be predicted. Finally, firm innovation activities are considered with the use of trade credit. Innovation with its variable of the same name takes a value of one if the firm has introduced a new product within the last three years, otherwise, its value is zero. It is found that innovative firms are in lack of bank finance rather than non-innovative firms because innovative firms are more information opaque (Mina et al., 2013; Ayyagari et al., 2011). In this respect, it is expected that innovative firms may ask for more supplier finance and hence, a positive relationship might be found between firm innovativeness and trade credit.

With respect to borrower-specific controls, borrower gender and experience are examined. Gender gets a value of one, if one of the owners of the firm is female and zero in all other cases. The research based on borrower gender and bank finance suggests that female borrowers are reluctant to access bank finance because they are afraid of rejection of their loan application (Muravyev et al., 2009; Belluchi et al., 2010). Cole (2010) in his sample found that female borrowers use more trade credit than male borrowers because it is easier to get trade credit. Henceforward, 
it may also be expected to find a positive relationship between trade credit and the female owner of the firm. The second borrower-specific variable is experience. It represents a number of years the owner is related to various businesses. Fatoki and Odeyemi (2010) find that borrower experience can positively affect the use of trade credit. An experienced borrower can negotiate more efficiently with the suppliers than an inexperienced owner, and can also get better trade credit terms.

Finally, the last field to control is the financial market development and the use of trade credit by small and medium enterprises in the examined countries. In this paper, the proxy variable for financial market development with a number of bank branches per 100,000 adults is applied (BRc). It may capture the effect of better financial intermediation activities by banks and thus firms may use less trade credit due to availability of bank finance. Hence, a negative relationship between financial market development and the use of trade credit is expected.

Tab. 1 - Variable definition. Source: authors' own

\begin{tabular}{|c|c|}
\hline Variable & Definition \\
\hline Trade Credit & $\begin{array}{l}\text { Percentage of material inputs or services purchased on credit } \\
(\%) \text {. }\end{array}$ \\
\hline \multicolumn{2}{|l|}{ External_Finance } \\
\hline Overdraft & Equals 1 if the firm has an overdraft facility $(0 ; 1)$ \\
\hline LOC & $\begin{array}{l}\text { Equals } 1 \text { if the firm has a line of credit or loan from a finan- } \\
\text { cial institution }(0 ; 1) \text {. }\end{array}$ \\
\hline LOC*Overdraft & $\begin{array}{l}\text { Equals } 1 \text { if the firm has access to both overdraft and a line of } \\
\text { credit facility. }\end{array}$ \\
\hline \multicolumn{2}{|c|}{ Firm_Characteristics } \\
\hline Size & $\begin{array}{l}\text { Size of the firm, measured as the number of full-time em- } \\
\text { ployees. Micro firms (1-9) employees, small firms (10-49) } \\
\text { employees, medium firms (50-250) employees. }\end{array}$ \\
\hline Age & $\begin{array}{l}\text { Age of firm, measured as the number of years that the firm } \\
\text { has been operating. }\end{array}$ \\
\hline Sector & $\begin{array}{l}1 \text { if the firm is a manufacturing firm; } 2 \text { when the firm is a } \\
\text { trade or wholesale firm; } 3 \text { when the firm is a service firm; } 4 \\
\text { when the firm is a construction and other business. }\end{array}$ \\
\hline Ownership & $\begin{array}{l}\text { Percentage ownership of the firm held by the largest share- } \\
\text { holder }(\%) \text {. }\end{array}$ \\
\hline Audit & $\begin{array}{l}\text { Equals } 1 \text { if the firm's financial statement is checked by exter- } \\
\text { nal auditors }(0,1) \text {. }\end{array}$ \\
\hline Quality & $\begin{array}{l}\text { Equals } 1 \text { if the firm has an internationally recognized quality } \\
\text { certification }(0,1) .\end{array}$ \\
\hline Crime & $\begin{array}{l}\text { Equals } 1 \text { if the firm has experienced any losses as a result of } \\
\text { theft, robbery, vandalism, or arson }(0,1)\end{array}$ \\
\hline
\end{tabular}




\begin{tabular}{|l|l|}
\hline Innovation & $\begin{array}{l}\text { Equals } 1 \text { if the firm has introduced any new products within } \\
\text { the last three years }(0,1) .\end{array}$ \\
\hline Borrower Characteristics & \multicolumn{2}{|l|}{ Equals 1 if one of the owner of the firm is a female. } \\
\hline Female & Experience of a top manager measured in years. \\
\hline Experience & \\
\hline Market_Structure & Number of bank branches per 100,000 adults \\
\hline BRc &
\end{tabular}

All the variables are collected from the BEEPS survey V, except for BRc. BRc is collected from the GFDD database. BEEPS = Business Environment and Enterprise Performance Survey. GFDD = Global Financial Development Database.

\section{RESULTS}

\subsection{Descriptive statistics}

Table 2 demonstrates descriptive statistics of this study. Trade credit is highly used by the firms of the examined countries, as it covers about $50 \%$ of their total purchases. Hence, with the initial information, it may be said that trade credit is a vital source of financial support for SMEs in the context of the examined countries. The data suggest that about $53 \%$ of the firms have an overdraft facility and about $40 \%$ of the firms have a line of credit facility from a financial institution. Therefore, they may suggest that SMEs have some access to external finance regardless of different financial barriers. It is also interesting to inspect the cross effect of overdraft and line of credit facility, as it is found that about $32 \%$ of the firms have access to both possibilities. Concerning firm characteristics, the data propose that $48 \%$ of the firms in the data set are small firms, whereas micro firms account for $34 \%$ and medium firms for $18 \%$. On the other hand, about $64 \%$ of the firms have been in business for more than 15 years, and it suggests that the sample largely consists of older and mature firms. Hereafter, it might be possible that older firms would ask for more bank finance than costly trade credit. Similarly, most of the firms in the data set are trade and wholesale firms - approximately 40\%. Moreover, a high concentration of business ownership structure at a level of about $76 \%$ is found, which suggests that a low number of owners mostly own the SMEs and it results in a concentrated ownership. Another fact is that $34 \%$ of the SMEs have an audit report and it suggests that these firms are not in a suitable position to produce audit reports by which they can reduce the information asymmetry. The data bring information that $31 \%$ of the firms in the data set have cooperated with innovation initiatives in the last three years and it is a positive sign for SMEs that they are not reluctant to involve them in their innovative activities. Last but not least, an interesting fact is brought into being in a field of business riskiness - about $19 \%$ of the firms in the examined countries are affected by theft, robbery, vandalism and arson. In this respect, it might be said that these activities may create a serious barrier for business survival, increase the risk of credit default, and have a positive effect on the use of trade credit. Considering firm owner characteristics, it is apparent that about $40 \%$ of the SMEs have a female owner, which may suggest that female participation in the business development is not significantly lower than that of male entrepreneurs. It is also possible to see that SMEs owners are highly experienced and they may have acquired excellent negotiation 
skills which they can use to ask for higher trade credits from the suppliers with proper credit terms. Finally, the ratios of bank branches per 100,000 adults range from 15 branches to 32 branches. Specifically, it is found that a higher number of bank branches are available in Poland where it reaches a maximum value, and a lower number of branches are found in Hungary with a minimum value of this dimension.

Tab. 2 - Descriptive statistics. Source: authors' calculation based on the BEEPS survey and GFDD database

\begin{tabular}{|c|c|c|c|c|}
\hline Variable & Mean & Std.Dev & Min & Max \\
\hline Trade_Credit & 49.1595 & 40.04019 & 0.00 & 100.00 \\
\hline \multicolumn{5}{|l|}{ External_Finance } \\
\hline Overdraft & 0.5276 & 0.49946 & 0.00 & 1.00 \\
\hline LOC & 0.3953 & 0.48912 & 0.00 & 1.00 \\
\hline LOC*Overdraft & 0.3164 & 0.46527 & 0.00 & 1.00 \\
\hline \multicolumn{5}{|l|}{ Firm_Characteristics } \\
\hline Micro & 0.3444 & 0.47539 & & \\
\hline Small & 0.4724 & 0.49946 & & \\
\hline Medium & 0.1832 & 0.38698 & & \\
\hline$<=5$ years & 0.307 & 0.17251 & & \\
\hline 6 to 10 years & 0.1174 & 0.32209 & & \\
\hline 11 to 15 years & 0.2138 & 0.41020 & & \\
\hline$>15$ years & 0.6380 & 0.48078 & & \\
\hline Manufacturing & 0.3111 & 0.46316 & & \\
\hline Trade & 0.3979 & 0.48968 & & \\
\hline Service & 0.1052 & 0.30691 & & \\
\hline Construction \& others & 0.1858 & 0.38912 & & \\
\hline Ownership & 75.9842 & 26.2655 & 9.00 & 100.00 \\
\hline Audit & 0.3488 & 0.47680 & 0.00 & 1.00 \\
\hline Quality & 0.3865 & 0.48716 & 0.00 & 1.00 \\
\hline Innovation & 0.3120 & 0.46352 & 0.00 & 1.00 \\
\hline Crime & 0.1912 & 0.39344 & 0.00 & 1.00 \\
\hline \multicolumn{5}{|l|}{ Borrower Characteristics } \\
\hline Female & 0.3970 & 0.48949 & 0.00 & 1.00 \\
\hline Experience & 20.3830 & 10.34678 & 1.00 & 125.00 \\
\hline \multicolumn{5}{|l|}{ Market_Structure } \\
\hline $\mathrm{BRc}$ & 25.9158 & 6.39481 & 15.35 & 32.53 \\
\hline
\end{tabular}

The table reports descriptive statistics for dependent variable and independent variables for full sample of firms. 


\subsection{Empirical results and discussion}

In Table 3, the OLS model with three different specifications of bank credit facilities (Overdraft and LOC) and their substitution effect on trade credit are presented. Model 1 examines the effect of overdraft facility (Overdraft) on trade credit. Model 2 examines LOC on trade credit and in model 3, the cross effect of overdraft and LOC (Overdraft*LOC) facility on the substitution effect of trade credit is shown.

Empirical results in Table 1 suggest that firms having an overdraft (Overdraft) facility from the banks use more trade credit than the firms that do not have the overdraft facility. Hence, opposite to the expectation, it can be confirmed that there is a complementary effect of bank credit on trade credit rather than the substitution effect. The results are similar to the results of Demirguc-Kunt \& Maksimovic (2001), as they find a complementary effect of trade credit and bank credit. Demirguc-Kunt \& Maksimovic (2001) argue that firms that access trade credit from their suppliers may signal positive information to the banks and hence they can access more bank finance, too. In Table 2 , there is a positive relationship between LOC and trade credit; however, the result is not statistically significant. Hence, as expected, having an LOC service from the bank may not replace the use of trade credit. Nevertheless, the insignificant positive result may indicate that firms that can access bank finance may ask for more trade credit. It could be suggested that firms having an LOC service from the banks can have more bargaining power and as a result, they can get more supplier finance. With respect to Overdraft*LOC (Table 3), an insignificant negative result is found and hence it cannot be assumed that firms having an Overdraft and LOC from financial institutions use less trade credit than the firms that do not have these financial services from the banks.

With respect to firm-level control variables, no significant differences between small and medium firms were found in comparison with micro firms in the use of trade credit. Hence, it cannot be confirmed that micro firms are more dependent on trade credit than small or medium firms because of their lack of external financial capacity. However, younger firms, firms aged within the range 5 years $(<=5)$ use more trade credit than the firms aged more than 15 years. The results are also in line with the results of Huyghebaert (2006), and Casey \& O'Toole (2014). These papers find that younger firms use more trade credit because they have a limited access to bank finance and financial constraints are higher for younger and new start-up firms. Huyghebaert (2006) also argues that firms in their start-up process have higher failure rates and because of that, banks are reluctant to finance them. Thus, younger firms are heavily dependent on trade creditors for their materials and supplies so that they can operate their businesses smoothly. In terms of sectorial differences and trade credit, the result suggests that service firms (Service) use significantly less trade credit finance in comparison to manufacturing firms. It could be suggested that manufacturing firms may have a stronger relationship with their suppliers and as a result, they can access more trade credits than service firms.

According to the expectation, a concentrated ownership (Ownership) structure of firms is associated with a higher use of trade credit, and the results are robust in different specifications. This result suggests that ownership concentrated entrepreneurs may have more incentives to 
use trade credit to hold their owner authority within the firm. The results are in line with the findings of Hughebaert (2006) in the context of Belgium. Entrepreneurs who value the private benefits of control are reluctant to ask for bank loans, as in the event of a loan, the default bank liquidation policy is quite strict in comparison with the trade creditors' liquidation strategies. Therefore, by requesting trade credit from the suppliers, the owners can hold their controlling power within the firm, even if the payment can be due for a certain time period. No effects of audit (Audit) report and ISO (Quality) quality certificate on the use of trade credit were found for the examined sample of firms. It is possible that firms' use of trade credit and the availability of audit reports and quality certificates are irrelevant. On the other hand, ISO quality certificates and audit reports may not be appropriate determinants of trade credit for the selected sample of firms. Considering the firm innovativeness and riskiness, the results suggest a positive relationship between innovation (Innovation) and crime (Crime) with the use of trade credit. As already mentioned elsewhere, innovative firms are information opaque, and as a result, they may prefer to purchase more on trade credit due to a limited access to formal bank finance. Similarly, high credit-risk firms may be reluctant to access bank finance because they might be rejected by the banks due to high credit risk. Casey \& O’Toole (2014) examine firm riskiness with firm debt to total asset and find that high-risk firms used more trade credit in their sample. On the other hand, suppliers maintain a close relationship with their customers, and hence trade creditors may lend more easily to these customers because they have more information about their default probability. Thus, credit constraints, innovative SMEs and high credit risk firms may find trade creditors as a suitable alternative source of financing for their business operations.

Empirical results for firm owner characteristics and trade credit suggest that there are no differences between male and female (Female) owner and the use of trade credit. It was expected that female borrowers would use more trade credit than male borrowers, as female borrowers have more credit constraints. However, the result of this paper may highlight the fact that male and female borrowers are receiving a similar level of preference from the trade creditors. On the other hand, the severity of credit constraints for female borrowers may not be applicable to the selected sample of firms, as it was found in the literature (Muravyev et al., 2009; Belluchi et al., 2010). However, there is a positive relationship between trade credit and owner experience (Experience), and the results are similar to those of Cole (2010) and Fatoki \& Odeyemi (2010). It suggests that the owners with a long history of business experience can access more trade credit from their suppliers. An experienced borrower can negotiate with their suppliers more efficiently and gain better credit terms. Therefore, owner business experience can be considered an important element of acquiring trade credit.

Last but not least, the results for financial market development do not show any significant effect on the use of trade credit. It was expected that as the financial market develops, it will be easier for SMEs to access loans from the bank, and they would use less trade credit. However, these results may highlight the fact that trade credit is an integral part of businesses, firms utilizing trade credit for their business operations, which is not related to the development of the banking sector. 
Tab. 3 - OLS regression for trade credit. Source: authors' own estimation

\begin{tabular}{|c|c|c|c|}
\hline Variable & $\begin{array}{l}\text { Model } 1 \\
\text { Trade Credit (\%) }\end{array}$ & $\begin{array}{l}\text { Model } 2 \\
\text { Trade Credit (\%) }\end{array}$ & $\begin{array}{l}\text { Model } 3 \\
\text { Trade Credit (\%) }\end{array}$ \\
\hline \multicolumn{4}{|l|}{ External_Finance } \\
\hline Overdraft & $12.293(2.355)^{* * *}$ & & \\
\hline LOC & & $1.511(2.427)$ & \\
\hline LOC* Overdraft & & & $-0.187(2.543)$ \\
\hline \multicolumn{4}{|l|}{ Firm_Characteristics } \\
\hline Small & $3.505(2.695)$ & $3.328(2.728)$ & $3.350(2.728)$ \\
\hline Medium & $4.572(3.72)$ & $4.601(3.746)$ & $4.586(3.765)$ \\
\hline$<=5$ years & $0.606(6.988)^{*}$ & $0.675(7.088)^{*}$ & $0.874(7.091) *$ \\
\hline 6 to 10 years & $3.415(3.772)$ & $3.269(3.820)$ & $3.352(3.820)$ \\
\hline 11 to 15 years & $-4.381(2.981)$ & $-3.781(3.014)$ & $-3.774(3.014)$ \\
\hline 2. Trade & $-2.830(2.910)$ & $-2.271(2.945)$ & $-2.325(2.947)$ \\
\hline 3. Service & $11.328(4.203)^{* * *}$ & $-10.470(4.250)^{* * *}$ & $-10.415(4.250)^{* * *}$ \\
\hline 4. Construction \& others & $-4.992(3.453)$ & $-5.127(3.495)$ & $-5.102(3.496)$ \\
\hline Ownership & $0.090(0.046)^{* *}$ & $0.086(0.046)^{* *}$ & $0.086(0.046)^{* *}$ \\
\hline Audit & $0.033(2.692)$ & $1.252(2.713)$ & $1.293(2.715)$ \\
\hline Quality & $-1.759(2.628)$ & $-2.433(2.565)$ & $-2.432(2.657)$ \\
\hline Innovation & $8.663(2.561)^{* * *}$ & $8.805(2.591)^{* * *}$ & $8.782(2.592)^{* * *}$ \\
\hline Crime & $6.658(2.990)^{* *}$ & $5.827(3.029)^{* *}$ & $5.928(3.305)^{* *}$ \\
\hline \multicolumn{4}{|l|}{ Borrower_Characteristics } \\
\hline Female & $-2.947(2.486)$ & $-2.710(2.518)$ & $-2.779(2.517)$ \\
\hline Experience & $0.214(0.119)^{*}$ & $0.260(0.120)^{* *}$ & $0.260(0.120)^{* *}$ \\
\hline \multicolumn{4}{|l|}{ Market_Structure } \\
\hline BRc & $0.264(0.195)^{* *}$ & $0.217(0.197)^{* *}$ & $0.205(0.197)^{* *}$ \\
\hline Constant & $36.769(8.358)^{* * *}$ & $29.798(8.496)^{* * *}$ & $30.598(8.452)^{* * *}$ \\
\hline Observations & 1140 & 1140 & 1140 \\
\hline
\end{tabular}

Statistical significance at the $10 \%, 5 \%, 1 \%$ level is indicated by *,**, *** respectively. Standard errors are in parentheses. Micro-sized firms, manufacturers and firms having been operating for more than 15 years are referenced categories for firm size, sector and age control.

\section{CONCLUSION}

In this paper, the substitution and complementary effect of bank credit on trade credit for SMEs is examined in the context of the Visegrad Group - the Czech Republic, Hungary, Poland, and the Slovak Republic. This paper utilizes 1,140 SMEs from the Business Environment and Enterprise Performance Survey, which is a joint project of the European Bank for Reconstruction and Development and the World Bank. The database is also complemented with the Doing Business report of the World Bank. The analysis examines bank overdraft and line of credit facility as a 
measure of bank finance. One of the main findings is that firms having an overdraft facility use more trade credit than firms without the overdraft facility. Hence, these results for overdraft facility validate the complementary effect of bank credit and trade credit rather than the substitution effect. However, no effect of a line of credit and cross effect of overdraft and line of credit on trade credit is found. The multiplication variable serves as the indicator of a cross effect. Some meaningful results for control variables appear in the analysis outcome. The results suggest that younger firms use more trade credit than older firms. It might be possible that younger firms have fewer options to finance their activities. Because of that, younger firms are willing to use more trade credit. Businesses with a high ownership concentration also use trade credit more than the dispersed ownership firms. Similarly, evidence that innovative firms and firms with a high credit risk are more dependent on trade creditors for their immediate business supplies and purchases is found in the outcome. The analysis results also suggest that owner experience can positively affect the use of trade credit. It is argued that an experienced borrower can negotiate more effectively with the trade creditors and that may help in acquiring more trade credit from the suppliers. However, the result of this paper suggests that service firms are less dependent on the trade creditors for their supplies and materials than manufacturing firms. These results are not only significant for the Visegrad Group, but might also be useful in other emerging and developed countries to understand the substitution effect of bank credit and trade credit. Nevertheless, this paper has a few limitations. At first, due to a large number of missing values, the firms based on each country level differentiation are not examined. However, it could be useful to understand the effect of bank credit on trade credit from each country level segmentation. Also, the effect of bank credit on trade receivables is not a part of the analysis, and this area can be considered in further research.

Acknowledgement:

This study was financially supported by the Internal Grant Agency of FaME TBU IGA/FaME/2017/010: Financial Constraints on Economic Activities.

\section{References}

1. Ardalan, F., Almasi, N. A., \& Atasheneh, M. (2017). Effects of contractor and employer's obligations in buy back contracts: case study of oil exporting country. Entrepreneurship and Sustainability Issues, 5 (2), 345-356. https://doi.org/10.9770/jesi.2017.5.2(13)

2. Adamowicz, M. \& Machla, A. (2016). Small and medium enterprises and the support policy of local government. Oeconomia Copernicana, 7 (3), 405-437. https://doi.org/10.12775/ OeC.2016.024

3. Ayyagari, M., Beck, T., \& Maksimovic, V. (2011). Firm innovation in emerging markets: the role of finance, governance, and competition. Journal of Financial and Quantitative Analysis, 46 (6), 1545-1580. https://doi.org/10.1017/S0022109011000378

4. Ayyagari, M., Beck, T., \& Demirgüç-Kunt, A. (2007). Small and medium enterprises across the globe. Small Business Economics, 29 (4), 415-434. https://doi.org/10.1007/s11187-006-90025

5. Bastos, R. \& Pindado, J. (2013). Trade credit during a financial crisis: A panel data analysis. Journal of Business Research, 66 (5), 614-620. https://doi.org/10.1016/j.jbusres.2012.03.015

6. Beck, T. \& Demirguc-Kunt, A. (2006). Small and medium-size enterprises: access to finance 
as a growth constraint. Journal of Banking and Finance, 30 (1), 2931-2943.

7. Beck, T., Demirguc-Kunt, A., \& Maksimovic, V. (2004). Financing patterns around the world: Are small firms different? World Bank Mimeo.

8. Belás, J., Rahman, A., Rahman, T., \& Schonfeld, J. (2017). Financial Constraints on Innovative SMEs: Empirical Evidence from the Visegrad Countries. Inqinerine EkonomikaEngineering Economics, 28 (5), 552-563.

9. Belas, J., Demjan, V., Habanik, J., Hudakova, M., \& Sipko, J. (2015). The business environment of Small and Medium enterprises in the selected regions of the Czech Republic and Slovakia. E+M Ekonomie a Management, 18 (1), 95-110.

10. Belluchi, A., Borisov, A., \&Zazzaro, A. (2010). Does gender matter in bank-firm relationships? Evidence from small business lending. Journal of Banking and Finance, 34 (1), 2968-2984.

11. Berger, A. \& Udell, G. F. (2002). Small business credit availability and relationship lending: the importance of bank organisational structure. The Economic Journal, 112(477), 32-53. https://doi.org/10.1111/1468-0297.00682

12. Berger, A., Espinosa-Vega, M. A., Frame, S., \& Miller, H. (2005). Debt maturity, risk, and asymmetric information. The Journal of Finance, LX (6), 2895-2923. https://doi.org/10.5089/ 9781451862201.001

13. Casey, E. \& O’Tolle, C. M. (2014). Bank lending constraints, trade credit and alternative financing during financial crisis: Evidence from European SMEs. Journal of Corporate Finance, 27 (1), 173-193.

14. Cassar, G. (2004). The financing of business start-ups. Journal of Business Venturing, 19, 261283.

15. Centineo, S. \& Centineo, S. (2017). Investment innovation trends: factor - based investing. Serbian Journal of Management, 12 (1), 65-75.

16. Cole, R. (2010). Bank credit, trade credit or no credit: evidence from the surveys of small business finance. Munich Personal RePEc Archive. https://mpra.ub.uni-muenchen.de/24689/

17. Coulibaly, B., Sapriza, H., \& Zlate, A. (2013). Financial frictions, trade credit, and the 2008 09 global financial crisis. International Review of Economics and Finance, 26 (1), 25-38.

18. Cuñat, V. (2007). Trade Credit: Suppliers as Debt Collectors and Insurance Providers. Review of Financial Studies, 20 (2), 491-527. https://doi.org/10.1093/rfs/hhl015

19. Daszkiewiz, N. (2014). Small and medium enterprises in Visegrad countries towards internationalisation changeless in the European Union. Retrieved from http://www.visegrad. uek.krakow.pl/PDF/Cartagena2014_ch09_daszkiewicz.pdf

20. Demirgüç-Kunt, A., \& Maksimovic, V. (2001). Firms as financial intermediaries: Evidence from trade credit data. Working paper. The World Banks.

21. Dobeš, K., Kot, S., Kramoliš, J., \& Sopková, G. (2017). The Perception of Governmental Support in The Context of Competitiveness of SMEs in the Czech Republic. Journal of Competitiveness, 9 (3), 34-50. https://doi.org/10.7441/joc.2017.03.03

22. Fatoki, O. \& Odeyemi, A. (2010). The determinants of trade credit by new SMEs in South 
Africa. African Journal of Business Management, 4 (13), 2763-2770.

23. García-Teruel, P.J. \& Martinez-Solano, P. (2010). Determinants of trade credit: A comparative study of European SMEs. International Small Business Journal, 28 (3), 215-233.

24. Giannetti, M., Burkart, M., \& Ellingsen, T. (2011). What you sell is what you lend? Explaining trade credit contracts. The Review of Financial Studies, 24 (4), 1261-1298.

25. Hanedar, E.Y., Broccardo, E., \& Bazzana, F. (2014). Collateral requirements of SMEs: the evidence from less developed countries. Journal of Banking and Finance, 38 (1), 106-121.

26. Huyghebaert, N. (2006). On the determinants and dynamics of trade credit use: Empirical evidence from business start-ups. Journal of Business Finance and Accounting, 33 (1), 305-328.

27. Huyghebaert, N. \& Van de Gucht L. (2004). Incumbent strategic behavior in financial markets and the exit of entrepreneurial start-ups. Strategic Management Journal, 25 (7), 669-688.

28. Huyghebaert, N., De Guchet, L., \& Van Hulle, C. (2007). The choice between bank debt and trade credit in business start-ups. Small Business Economics, 29 (1), 435-452.

29. Ivanová, E. (2017). Barriers to the development of SMEs in the Slovak Republic. Oeconomia Copernicana, 8 (2), 255-272. https://doi.org/10.24136/oc.v8i2.16.

30. Kirschemann, L. (2016). Credit rationing in small firm bank relationships. Journal of Financial Intermediation, 26 (1), 68-99.

31. Ključnikov, A., Kozubíková, L., \& Sopková, G. (2017). The Payment Discipline of Small and Medium-sized Enterprises. Journal of Competitiveness, 9 (2), 45-61. https://doi.org/10.7441/ joc.2017.02.04

32. Ključnikov, A. \& Belas, J. (2016). Approaches of Czech entrepreneurs to debt financing and management of credit risk. Equilibrium. Quarterly Journal of Economics and Economic Policy, 11 (2), 343-365. https://doi.org/10.12775/EQUIL.2016.016

33. Kozubíkova, L., Homolka, L., \& Kristalas, D. (2017). The Effect of Business Environment and Entrepreneurs' Gender on Perception of Financial Risk in The SMEs Sector. Journal of Competitiveness, 9 (1), 36-50. https://doi.org/10.7441/joc.2017.01.03

34. Kozubíková, L., Belás, J., Bilan, Y., \& Bartoš, P. (2015). Personal characteristics of entrepreneurs in the context of perception and management of business risk in the SME segment. Economics and Sociology, 8 (1), 41-54. https://doi.org/10.14254/2071- 789X.2015/8$1 / 4$

35. Lin, T. \& Chou, J. (2015). Trade credit and bank loan: Evidence from Chinese Firms. International Review of Economics and Finance, 36 (1), 17-29.

36. Love, I., Preve, L. A., \& Allende, V. S. (2007). Trade credit and bank loan: Evidence from recent financial crises. Journal of Financial Economics, 83 (2), 453-469.

37. Menkhoff, L., Neuberger, D., \& Rungruxsirivorn, O. (2012). Collateral and its substitutes in emerging markets lending. Journal of Banking and Finance, 36 (1), 817-834.

38. Meyer, D. F., \& Meyer, N. (2017). Management of small and medium enterprise (SME) development: An analysis of stumbling blocks in a developing region. Polish Journal of Management Studies, 16 (1), 127-141. 
39. Mina, A., Lahr, H., \& Hughes, A. (2013). The demand and supply of external finance for innovative firms. Industrial and Corporate Change, 22 (4), 896-901.

40. Monni, S., Novelli, G., Pera, L., \& Realini, A. (2017). Workers' buyout: the Italian experience, 1986-2016. Entrepreneurship and Sustainability Issues, 4 (4), 526-539. https://doi.org/10.9770/ jesi.2017.4.4(10)

41. Muravyev, A., Talavera, O., \& Schäfer, D. (2009). Entrepreneurs' Gender and Financial Constraints: Evidence from International Data. Journal of Comparative Economics, 37 (1), 270 286.

42. Rahman, A., Belas, J., Kliestik, T., \& Tyll, L. (2017). Collateral requirements for SME loans: empirical evidence from the Visegrad countries. Journal of Business Economics and Management, 18 (4), 650-675. https://doi.org/10.3846/16111699.2017.1357050

43. Rahman, A., Rahman, M. T., \& Kljucnikov, A. (2016). Collateral and SME financing: an analysis across bank size and bank ownership types. Journal of International Studies, 9 (2), 112 126.

44. Rajnoha, R. \& Lorincová, S. (2015). Strategic Management of Business Performance Based on Innovations and Information Support in Specific Conditions of Slovakia. Journal of Competitiveness, 7 (1), 3-21. https://doi.org/10.7441/joc.2015.01.01

45. Simionescu, M., Lazányi, K., Sopková, G., Dobeš, K., \& Balcerzak, A. P. (2017). Determinants of Economic Growth in V4 Countries and Romania. Journal of Competitiveness, 9 (1), 103-116. https://doi.org/10.7441/joc.2017.01.07

46. Slavec, A. (2014). Bank financing and trade credit use of Slovenian small firms: An empirical examination. Transformations in Business and Economics, 13 (2), 91-101.

47. Sobekova Majkova, M. (2016). The Relationship between the Risk of a Change of the Interest Rate and the Age of Entrepreneurs among Slovak SMEs. Journal of Competitiveness, 8 (3), 125138. https://doi.org/10.7441/joc.2016.03.08

48. Tsuruta, D. (2013). Credit contagion and trade credit: evidence from small business data in Japan. Asian Economic Journal, 27 (4), 341-367.

49. Tvaronavičienè, M. \& Razminienè, K. (2017). Towards Competitive Regional Development Trough Clusters. Journal of Competitiveness, 9 (4), 133-147. https://doi.org/10.7441/ joc.2017.04.09

50. Yang, X. (2011). The role of trade credit in the recent subprime financial crisis. Journal of Economics and Business, 63 (5), 517-529.

51. Virglerova, Z., Dobes, K., \& Vojtovic, S. (2016). The Perception of the State's Influence on Its Business Environment in SMEs from the Czech Republic. Administratie si Management Public, 14 (26), 78-96.

52. Vojtovič, S. (2016). The Impact of The Structural Funds on Competitiveness of Small and Medium-Sized Enterprises. Journal of Competitiveness, 8 (4), 30-45. https://doi.org/10.7441/ joc.2016.04.02

53. Zapletalová, S. (2017). Competitive Strategies of the SMEs: Empirical Evidence from the Czech Republic. Forum Scientiae Oeconomia, 5 (3), 9-26. 


\section{Contact information}

Ashiqur Rabman

Tomas Bata University in Zlín

Faculty of Management and Economics

Department of Enterprise Economics

Czech Republic

E-mail:rabman@utb.cr.

Dr. Zoltan Rozsa, Ph.D

School of Economics and Management in Public Administration in Bratislava

Department of Management

Slovakia

E-mail:Zoltan.rozsa@vsemvs.sk

ORCID: 0000-0002-3699-6669

Dr. Martin Cepel, Ph.D.

Paneuropean University Bratislava

Faculty of Economics and Business

Slovakia

E-mail: cepel@benzinol.com. 